\title{
Role of Fibroblast Growth Factor Receptor 2 in Kidney Mesenchyme
}

\author{
DAVID HAINS, SUNDER SIMS-LUCAS, KAYLE KISH, MONALEE SAHA, KIRK MCHUGH, AND CARLTON M. BATES \\ Center for Cell and Developmental Biology [D.H., S.S.-L., K.K., M.S., K.M., C.M.B.], The Research Institute at Nationwide Children's \\ Hospital, Columbus, Ohio 43205; Department of Pediatrics [D.H., C.M.B.], The Ohio State University College of Medicine, \\ Columbus, Ohio 43210
}

\begin{abstract}
Conditional deletion of murine fibroblast growth factor receptors $(F g f r s) 1$ and 2 in metanephric mesenchyme leads to renal agenesis with unbranched ureteric buds; however, there are occasionally two buds per nephric duct. Our goal was to determine whether conditional deletion of Fgfrl or Fgfr2 alone resulted in multiple ureteric bud induction sites. Although deletion of Fgfrl alone results in no abnormalities, loss of $F g f r 2$ often leads to multiple ureteric buds and anomalies including renal aplasia, misshaped kidneys, partially duplicated kidneys, duplicated ureters, and obstructed hydroureter. Deletion of Fgfr2 did not change expression domains of glial cell line-derived neurotrophic factor (GDNF), Robo2, bone morphogenetic protein 4, or Sproutyl, all of which regulate ureteric bud induction. Cultured Fgfr2 mutant nephric ducts were also not more sensitive to exogenous GDNF than controls. Whole mount in situ hybridization revealed that in mutant embryos, Fgfr 2 was deleted from stromal cells around the nephric duct and ureteric bud base, which correlates well with the ureteric bud induction abnormalities. Thus, Fgfr2 is critical in ensuring that there is a single ureteric bud from the nephric duct. The plethora of later stage defects in Fgfr2 conditional knockouts is reminiscent of many human cases of genetic urogenital anomalies. (Pediatr Res 64: 592-598, 2008)
\end{abstract}

$\mathrm{F}_{\mathrm{r}}^{\mathrm{i}}$ broblast growth factor receptors ( Fgfrs) are receptor tyrosine kinases with four known signaling members and 22 ligands in mammals (1). Fgfrs are expressed throughout embryogenesis in many tissues, including the kidney (1).

The metanephric kidney arises from two embryonic tissues, the metanephric mesenchyme and ureteric bud. At embryonic day (E) 10.5 in the mouse and the 5th week of gestation in humans, the metanephric mesenchyme induces a single ureteric bud from the Wolffian (nephric) duct near the hind limb (2). Subsequently, the ureteric bud elongates and branches within the metanephric mesenchyme, giving rise to the collecting ducts, pelvis, and ureter (2). At its tips, the ureteric bud induces local metanephric mesenchyme to condense and differentiate into nephron epithelia. Regions of stromal mesenchyme also surround the developing nephrons.

Received March 27, 2008; accepted July 22, 2008.

Correspondence: Carlton M. Bates, M.D., Center for Cell and Developmental Biology, The Research Institute at Nationwide Children's Hospital, 700 Children's Drive, Columbus, OH 43205; e-mail: carl.bates@nationwidechildrens.org

Supported by NIH R01 DK070030-01 (to C.M.B.).
Many studies have documented diverse actions of Fgfrs in developing kidneys. Addition of $F g f 2$ to isolated rat metanephric mesenchymal tissues prevented apoptosis $(3,4)$ and promoted condensation (4). Transgenic mice with a dominant negative $F g f r$ fragment developed renal agenesis/severe dysgenesis (5). Mice null for $\mathrm{Fgf7}$, FgflO, or Fgfr2-IIIb (the receptor isoform for $\mathrm{Fgf7}$ and $F g(10)$, have small kidneys with normal-appearing nephrons (6-8). Mice with conditional deletion of Fgf8 from the metanephric mesenchyme, however, have interrupted nephron development $(9,10)$.

Although $F g f r 1$ and $F g f r 2$ null mice are early embryonic lethal (11-14), conditional knockout approaches have revealed roles for these receptors in kidney development. We observed that deletion of $F g f r 2$ from the ureteric bud results in aberrant ureteric bud and renal stromal patterning (15). We also demonstrated that loss of both $\mathrm{Fgfrl}$ and $\mathrm{Fgfr} 2$ from the metanephric mesenchyme (Fgfrl/2 ${ }^{\text {Mes-/- }}$ ) leads to renal agenesis (16). Although Fgfrl/ $2^{\text {Mes-1- }}$ embryos had unbranched ureteric buds, there are occasionally two buds from one nephric duct (16). Our goal was to determine whether there were ureteric bud induction abnormalities in either $\mathrm{Fgfr} \mathrm{Mes}^{\mathrm{Me-}-}$ or $\mathrm{Fgfr} 2^{\mathrm{Mes}-/-}$ mice and subsequent developmental consequences.

\section{METHODS}

Fgfr $2^{\mathrm{Mes}-/-}$ and Fgfr2 $2^{\mathrm{UB}-/-}$ conditional knockout mice. This study was approved by the Research Institute at Nationwide Children's Hospital Institutional Animal Care and Use Committee. The conditional knockout mice have been described previously $(15,16)$. Briefly, transgenic mice with the Pax3 promoter driving cre recombinase expression in metanephric mesenchyme $\left(\mathrm{Pax}_{3} \mathrm{cr} \mathrm{Cg}^{\mathrm{Tg} /+}\right.$ ) (gift from Dr. Jon Epstein, University of Pennsylvania, Philadelphia) were crossed with mice possessing lox-p sites that flank a critical portion of Fgfr2 (Fgfr2 ${ }^{\text {Lox/Lox }}$ ) (gift from Dr. David Ornitz, Washington University, St. Louis). Transgenic mice with a portion of the HoxB7 promoter driving cre recombinase expression $\left(\right.$ Hoxb $\left.7 \mathrm{cre} \mathrm{Tg}^{T /+}\right)$ were also crossed with $F g f r 2^{L o x / L o x}$ mice. Progeny with cre and two lox-p sites had functional deletion of Fgfr2 from the metanephric mesenchyme (Pax3 $\left.\mathrm{cre}^{T g /+} / F g f r 2^{\text {Lox/Lox }}\right)$ or the nephric duct and ureteric bud (Hoxb7cre $\left.e^{T g /+} / F g f r 2^{L o x / L o x}\right)$, respectively. Littermates with all other genotypes were phenotypically normal and used as controls.

Abbreviations: Bmp4, bone morphogenetic protein 4; E, embryonic; $\boldsymbol{F} \boldsymbol{g} \boldsymbol{f r}$, fibroblast growth factor receptor; $\boldsymbol{F g} \boldsymbol{g r}^{\mathrm{Mes-}-\text { - }}$, conditional deletion of $\mathrm{Fg} f r$ from the metanephric mesenchyme; $\boldsymbol{F} \boldsymbol{g} \boldsymbol{F r}^{\boldsymbol{U B} \mathbf{-}^{-}-}$, conditional deletion of $\mathrm{Fgfr}$ from the ureteric bud; GDNF, glial cell-line derived neurotrophic factor 
Table 1. PCR primers used for genotyping

\begin{tabular}{ccc}
\hline Gene & Primers & $\begin{array}{c}\text { Size } \\
\text { (base pairs) }\end{array}$ \\
\hline Pax3cre & 5'-AATCTTATGGTCAC & 230 \\
& CTGAGTGTTAAAT & \\
& GTCCAATTTAC-3' & \\
Fgfr2 & 5'-CATCTTCAGGT & \\
& TCTGCGGG-3' & $307(\mathrm{wt})$ \\
& 5'-GTCAATTCTAA & \\
& GCCACTGTCTGCC-3' & 373 (floxed) \\
& 5'-CTCCACTGATTAC & \\
\hline
\end{tabular}

Table 2. Probe templates used for in situ hybridization

\begin{tabular}{lcc}
\hline Probe & GenBank accession \# & Nucleotide \#'s \\
\hline Ret & BC059012 & $3205-3688$ \\
Gdnf & NM010275 & $2894-3428$ \\
Pax2 & NM011037 & $450-937$ \\
Fgfr 2 & X55441 & $1594-1941$ \\
BMP4 & D14814 & $8378-8605$ \\
\hline
\end{tabular}

Genotyping. Tail clippings and/or embryonic heads were used to extract DNA for polymerase chain reaction genotyping using primers (Table 1) as described $(15,16)$.

Histology. E16.5 Fgfr2 ${ }^{\mathrm{Mes}-1-}$ and control littermates were dissected, fixed in $4 \%$ paraformaldehyde in phosphate buffered-saline overnight at $4{ }^{\circ} \mathrm{C}$, and then embedded in paraffin. Sections of $4-10 \mu \mathrm{m}$ were stained with hematotxylin and eosin. Whole-mount in situ hybridization was performed on E10.5 to E11.5 Fgfr2 ${ }^{\mathrm{Mes}-/-}$ and control embryos and/or dissected kidneys as described previously (16). Digoxigenin-UTP-labeled antisense and sense RNA probes were generated against multiple targets (Table 2). The Sproutyl probe template was published previously (17). Some whole mount in situ hybridization-stained tissues were re-embedded in paraffin and sectioned at $10 \mu \mathrm{m}$. In addition, radioactive in situ hybridization was performed on E11.5 Fgfr2 ${ }^{\mathrm{Mes}-1-}$ and control embryos with probes against Fgfr2, as described (16).

Organ cultures. E10.5 Fgfr $2^{\text {Mes-l- }}$ and control littermate nephric ducts and surrounding mesenchyme were dissected and grown on nucleopore filters floating on Dulbecco's modified Eagle medium with 10\% fetal bovine serum at $37^{\circ} \mathrm{C}$ for $3 \mathrm{~d}$. In addition to serum, only ( $n=24$ control and $n=15$ nephric ducts) recombinant human glial cell-line derived neurotrophic factor (GDNF) (R\&D Systems) was added at $25 \mathrm{ng} / \mathrm{mL}(n=16$ control, $n=8$ mutant) and $50 \mathrm{ng} / \mathrm{mL}$ ( $n=18$ control and $n=10$ mutant) as described (18). Tissues were fixed in methanol and immunofluorescence was performed against Calbindin$\mathrm{D}_{28 \mathrm{k}}$ (Sigma Chemical Co.-Aldrich) to visualize nephric ducts and ureteric buds, as described (19).

Microscopy and photography. GDNF and Robo2 expression domains were measured for long axis length and planar surface area, and GNDF domains were assessed for maximum width and length of posterior limit of signal to midpoint of hind limb using ImageJ (version 1.32 $\mathrm{j}$ from Wayne Rasband, National Institutes of Health, USA). All images were captured on an AxioCam digital camera (Zeiss, Thornwood, NY) mounted on a DM LB microscope (Leica, Wetzlar, Germany) and then converted to Adobe Photoshop files.

\section{RESULTS}

Fgfr2 $2^{\mathrm{Mes}-/-}$ mice have ureteric bud induction abnormalities resulting in many aberrant phenotypes. To determine whether deletion of $F g f r l$ or $F g f r 2$ from the metanephric mesenchyme causes ureteric bud induction abnormalities, we performed whole mount in situ hybridization on E10.5 to E11.5 embryos for Ret, a marker of the nephric duct and ureteric bud. We detected no abnormalities in Fgfrl $\mathrm{Mes}^{\text {M- }-}$ mice (data not shown) or in controls (Fig. $1 a$ and $c$ ). In contrast, $67 \%(8 / 12)$ of the Fgfr $2^{\text {Mes-1- }}$ embryos had two ureteric buds from one nephric duct (50\% unilateral and $17 \%$ bilateral) (Fig. $1 b, d$, and $e$ ). No Fgfr $2^{\text {Mes-l- }}$ mice had more

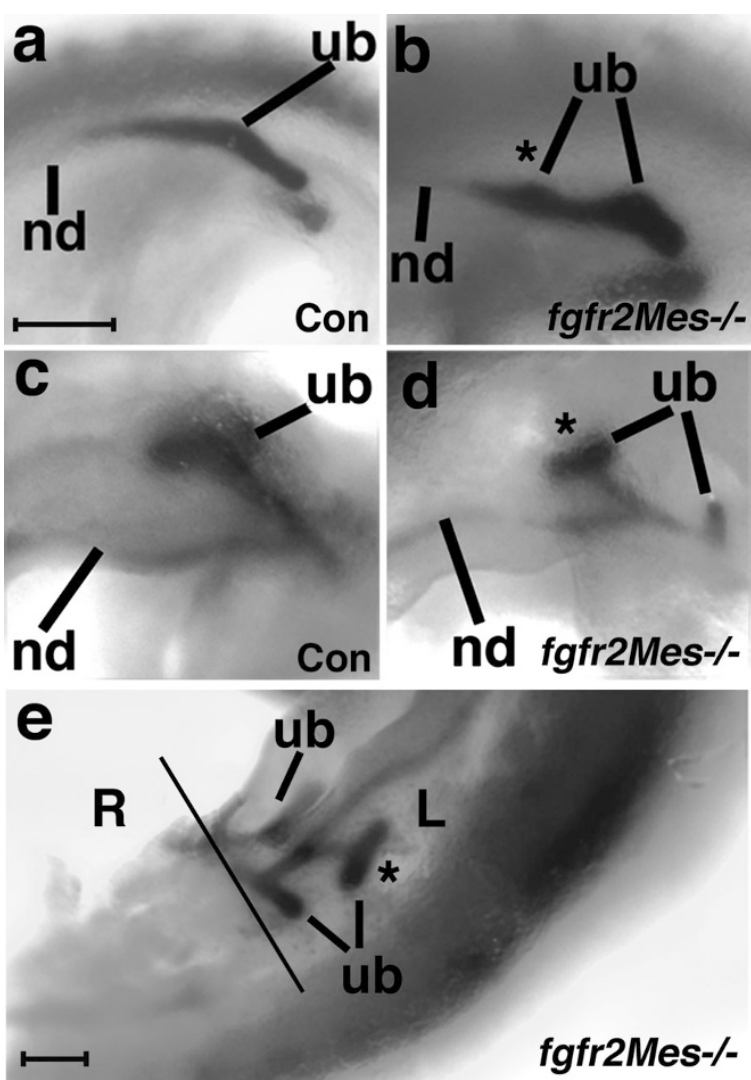

Figure 1. Whole mount in situ hybridization for Ret in $\mathrm{Fgfr}^{\mathrm{Mes}-1-}$ and control embryos. $a$, Control E10.5 embryo with nephric duct (nd) and single ureteric bud (ub) at its normal position. $b, F_{\text {f }} \mathrm{r}^{\text {Mes- }}{ }^{-}$E10.5 embryo with two ureteric buds from one nephric duct, including an anterior bud (asterisk) and a more properly positioned bud. $c$, Control E11.5 embryo with a single normally positioned ureteric bud that has elongated and branched. $d$, $\mathrm{Fgfr}^{\text {Mes- }}{ }^{-}$E11.5 embryo with elongation and branching of the anterior ureteric bud (asterisk) and minimal elongation and no branching of the more normally-positioned bud. e, Fgfr2 ${ }^{\text {Mes-1- }}$ E11.5 embryo with a right-sided (R) single, properly-positioned ureteric bud, but a left-sided $(L)$ anterior bud that has elongated and branched (asterisk) and a more normally-positioned bud has elongated less and has not appreciably branched (also note that the trajectory of the left anterior bud appears more appropriate than the more normally-positioned bud). Scale bars $=100 \mu \mathrm{m}$.

than two ureteric buds per side. At E10.5, the affected F gfr $2^{\text {Mes-I- }}$ mice possess one ureteric bud at or near the normal position and one that is anterior (cranial) along the nephric duct (Fig. 1b). By E11.5, one of the two ureteric buds on one side had elongated and branched within the metanephric mesenchyme, whereas the other was shorter with blunted branching and/or had an inappropriate trajectory (Fig. $1 d$ and $e$ ). Thus, a majority of $\mathrm{Fg} f r 2^{\text {Mes-l- }}$ embryos had two ureteric buds from one nephric duct, although only one of the two made good contact with the metanephric mesenchyme.

We then examined E16.5 embryos to determine how the ureteric bud induction abnormalities affected later stages of renal development. Approximately $37 \%$ (4 of 11) Fgfr $2^{\text {Mes- }-}$ embryos examined had abnormalities (50\% bilateral and 50\% unilateral). Phenotypes included duplex ureters ( $n=2$ complete, $n=1$ partial), hydroureter $(n=3)$, partial duplex kidneys $(n=2)$, misshaped kidneys $(n=2)$, and renal agenesis $(n=1)$ (Figs. 2 and 3; and data not shown). Fgfr2 $2^{\text {Mes-l- }}$ mice with bilateral abnormalities usually had different urogenital phenotypes on either side 


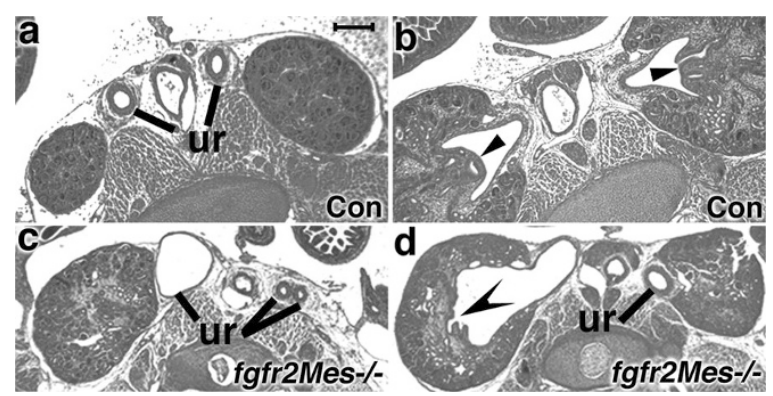

Figure 2. Transverse hematoxylin and eosin (H\&E) sections of E16.5 control and Fgfr $2^{\text {Mes-1- }}$ kidneys: $a$ and $b$, Control embryo with normal caliber ureters $(a, u r)$ that empty into a renal pelvis with a normal papilla $(b$, arrowhead). $c$ and d,: Fgfr $2^{\text {Mes-1- }}$ embryo with a massive hydroureter on one side ( $c$, ur-one line) that empties into a flattened renal pelvis $(d$, concave arrowhead) and duplicated ureters on the other side (c, ur-two lines) that coalesce into a single ureter entering the kidney $(d, u r)$. Scale bar $=250 \mu \mathrm{m}$.

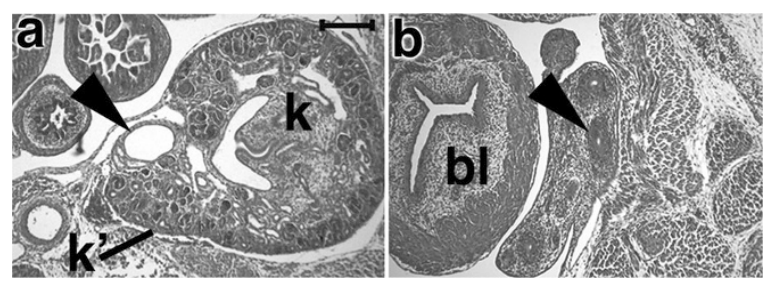

Figure 3. Transverse hematoxylin and eosin (H\&E) sections of an E16.5 Fgfr $2^{\text {Mes-1- }}$ female embryo from the renal pelvis ( $a$ ) and the bladder (b). $a$, Partial duplex kidney with a hydroureter (arrowhead) draining a smaller, misshapen kidney moiety $(k$ ') fused to a more normal-appearing kidney $(k) . b$, The hydroureter ends blindly in a fibrotic mass in the paramesonephros near the bladder $(b l)$. Scale bar $=250 \mu \mathrm{m}$.

(Fig. 2; and data not shown). To determine whether mutants with hydroureter had aberrant bladder insertion, we obtained serial cross sections of ureters from the renal pelvis to the bladder. One female $\mathrm{Fgfr}^{\mathrm{Mes}-1-}$ embryo had a hydroureter (Fig. 3a, arrowhead) and an ipsilateral more normal ureter that were both attached to a partially duplex kidney (the hydroureter to the small, abnormally-positioned "kidney" and the normal ureter to appropriately contoured "kidney"). In caudal sections (Fig. 3b), the hydroureter ends in the paramesonephros whereas the normal ureter inserts into the bladder (data not shown). Thus, at later ages, a number of $\mathrm{Fgfr}^{\mathrm{Mes}-1-}$ embryos display a wide range of urogenital abnormalities.

GDNF and Robo 2 expression is unaltered in $\mathrm{Fgfr}^{\mathrm{Mes}-1-}$ mutants. Some mouse models have multiple ureteric bud induction sites from shifted and/or expanded expression domains of glial cell line-derived neurotrophic factor (GDNF) in the metanephric mesenchyme $(20,21)$. Because $F g f r 2$ is deleted from the metanephric mesenchyme in $\mathrm{Fgfr} 2^{\text {Mes-1- }}$ mice (16), it is plausible that altered GDNF expression could explain the abnormalities in Fgfr2 $2^{\text {Mes-I- }}$ mice. Thus, we performed whole mount in situ hybridization for GDNF in Fgfr2 ${ }^{\text {Mes-l- }}$ and control E10.5 embryos. Both controls and mutants had "tear-shaped" GDNF expression patterns with antisense probes (Fig. $4 a$ and $b$, respectively), and neither had signal with sense probes (data not shown). To compare the expression domains of GDNF in control and $\mathrm{Fgfr}^{\mathrm{Mes}-1-}$ embryos, we calculated the maximal width (A), area (B), long axis length (C), and distance from the posterior expression limit to the midpoint of the hind limbs (D) (Fig. 4c). We found no differences in the size or position of the GDNF signal between control $(n=10)$ and $F g f r 2^{\text {Mes-l- }}$ mutants $(n=12)$ (Table 3). Thus, GDNF expression domain is unaltered in Fgfr2 ${ }^{\text {Mes-l- }}$ embryos.

Given that alterations in Robo2 expression have been reported in models of aberrant ureteric bud induction, we performed whole mount in situ hybridization against Robo2 in Fgfr2 ${ }^{\text {Mes-l- }}$ and control E10.5 embryos (20). As with GDNF, we detected no differences between control and mutant long axis length $(766 \pm 95.8 \mu \mathrm{m}$ versus $737 \pm 28.1 \mu \mathrm{m}, p=0.32)$ or surface area $\left(86.778 \pm 13.6 \mu \mathrm{m}^{2}\right.$ versus $83.9 \pm 15.4 \mu \mathrm{m}^{2}$, $p=0.60$ ) (Fig. 5).

Fgfr2 is deleted from stromal mesenchymal cells adjacent to nephric ducts and main ureteric bud trunks in Fgfr2 ${ }^{\text {Mes-l- }}$ mice. Other mouse lines develop multiple ureteric bud induction sites secondary to perturbations in the stromal cells surrounding the nephric duct and the main ureteric bud trunk (22). Thus, we determined whether Fgfr2 is normally expressed in these stromal cells and whether expression is deleted in $\mathrm{Fgfr} \mathrm{Fes-I-}^{\mathrm{Mes}}$ mice by whole mount in situ hybridization in isolated E11.5 kidney tissues. In controls ( $n=5$ embryos), we detected $F g f r 2$ in a wide band that seems to be present in the nephric duct and ureteric bud trunk epithelia, and the surrounding stromal mesenchymal cells (Fig. 6a). In Fgfr2 ${ }^{\text {Mes-l- }}$ tissues $(n=5$ embryos); however, Fgfr2 is expressed in a much more thin band, that seems to be localized to the nephric duct and ureteric bud trunk epithelium only (and absent from the stromal mesenchymal cells) (Fig. $6 b$ ). We next examined $\mathrm{Fgfr} 2$ expression in $\mathrm{Hoxb}_{\mathrm{cre}} \mathrm{Cg}^{\mathrm{T}+} /$ Fgfr2 ${ }^{\text {Lox/Lox }}$ kidney tissues ( $n=8$ embryos), which selectively deletes $F g f r 2$ from the ureteric bud and nephric duct epithelium (15). In $\mathrm{Hoxb} 7 \mathrm{cre} \mathrm{Cg}^{\mathrm{Tg}+} / \mathrm{Fgfr} 2^{\mathrm{Lox} / \mathrm{Lox}}$ tissues, we detected linear Fgfr2 expression only in stromal cells on either side of the nephric duct and ureteric bud epithelia (Fig. $6 c$ ). There was no signal in tissues incubated with sense probes (data not shown).

To confirm the whole mount data, we performed radioactive in situ hybridization for $F g f r 2$ on E10.5 control and $\mathrm{Fgfr} 2^{\mathrm{Mes}-l-}$ tissue sections. In controls, Fgfr2 is expressed in metanephric mesenchyme, ureteric bud ampullae, ureteric trunk, and stromal tissue surrounding ureteric trunk epithelium (Fig. 7a, a', arrow). In Fgfr2 $2^{\text {Mes-l- }}$ embryos, however, Fgfr2 is present in ureteric epithelium within the metanephric mesenchyme and the early trunk exiting the mesenchyme and the nephric duct, but not in metanephric or stromal mesenchyme) (Fig. $7 c, c^{\prime}$ ). Near the ureteric trunk and the nephric duct junction, Fgfr2 is expressed in the epithelia and the stromal cells between the epithelia in controls (Fig. 7b, b', arrowhead), whereas it is present only in the epithelial tissues in mutants and not the stromal strip (Fig. 7d, d', arrowhead). Taken together, $F g f r 2$ is normally expressed in stromal cells adjacent to the nephric duct and main ureteric bud trunks and is deleted from these mesenchymal cells in Fgfr $2^{\mathrm{Mes-1-}}$ mice.

Bone morphogenetic protein 4 expression is unaltered in Fgfr2 ${ }^{\text {Mes-I- }}$ mice. . Because $F g f r 2$ seems to be deleted in the aforementioned mesenchymal cells in $\mathrm{Fgfr} 2^{\mathrm{Mes}-1-}$ mice, we examined whether the mutants had altered expression of stromal bone morphogenetic protein 4 (Bmp4), a known antago- 

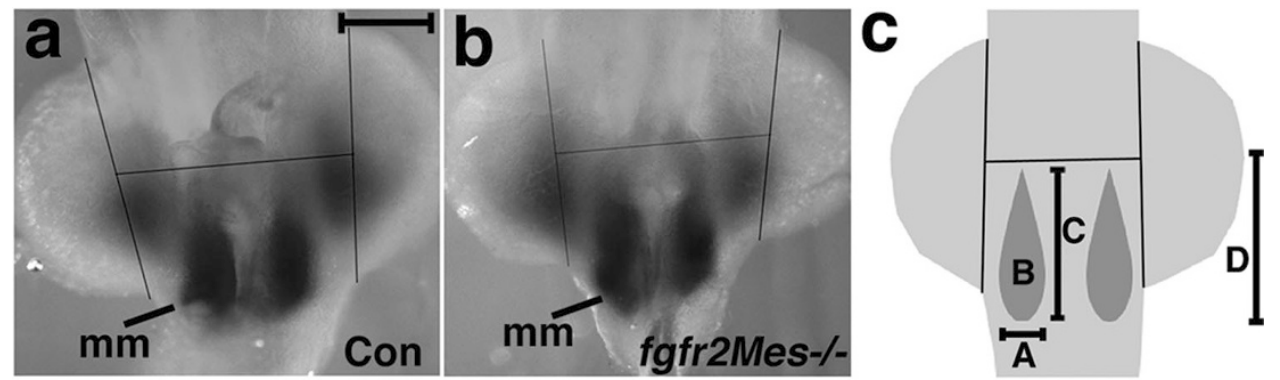

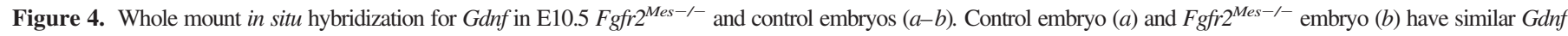

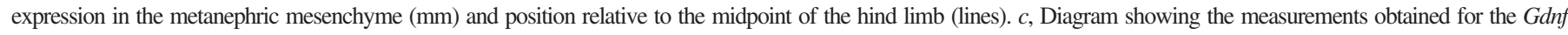

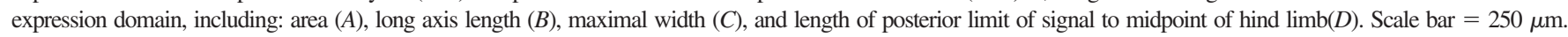

Table 3. Measurements of Gdnf expression domains in Fgfr $2^{\text {Mes-1- }}$ and control embryos

\begin{tabular}{lccc}
\hline \multicolumn{1}{c}{ Gdnf measurement } & Control $(\mu \mathrm{m})$ & Mutant $(\mu \mathrm{m})$ & $p$-value \\
\hline A. Maximal width (mean \pm SD) & $174 \pm 18.5$ & $164 \pm 31.3$ & 0.45 \\
B. Area (mean \pm SD) & $81.5 \pm 15.2$ & $79.1 \pm 20.5$ & 0.78 \\
C. Long axis length (mean \pm SD) & $613 \pm 129$ & $622 \pm 127$ & 0.87 \\
D. Posterior to mid hind limb (mean \pm SD) & $1377 \pm 206$ & $1335 \pm 156$ & 0.62 \\
\hline
\end{tabular}
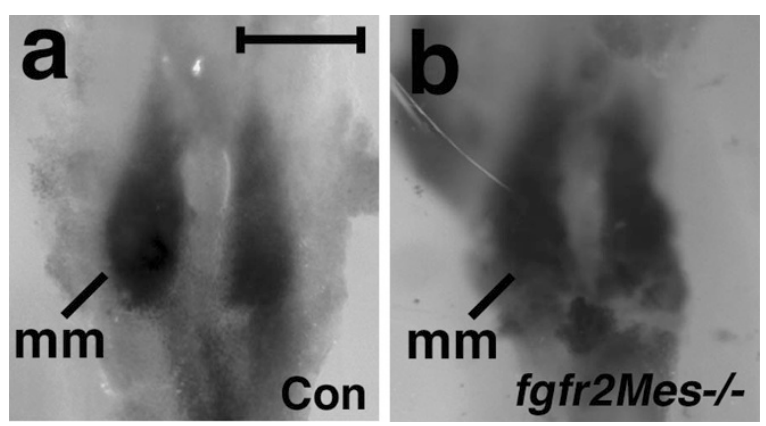

Figure 5. Whole mount in situ hybridization for Robo2 in E10.5 Fgfr ${ }^{\text {Mes-/- }}$ and control embryos. Control (a) and Fgfr $2^{\text {Mes-/- }}$ embryos (b) have similar Robo 2 expression patterns in the metanephric mesenchyme $(\mathrm{mm})$. Scale bar $=250 \mu \mathrm{m}$.

nist of ureteric bud induction (22). In E11.5 kidney tissues, both control ( $n=19$ embryos $)$ and Fgfr $2^{\text {Mes-I- }}(n=8$ embryos) displayed linear Bmp4 signal in the stromal cells adjacent to the nephric duct and the ureteric bud (Fig. 8), including mutants with two ureteric buds arising from one nephric duct (data not shown). We observed no signal in tissues incubated with sense probe (data not shown). Thus, Bmp4 expression seems to be unaltered in $\mathrm{Fg} f \mathrm{r}^{\mathrm{Mes}-1-}$ embryonic kidneys.

Sprouty1 expression is not altered in Fgfr ${ }^{M e s-/-}$ mice. As in Fgfr $2^{\text {Mes-1- }}$ mice, Sproutyl null mice develop multiple ureteric bud induction sites without alterations in either GDNF or Bmp4 expression (17). Given that Sproutyl transcription is also stimulated by $F g f r$ signaling, we performed whole mount in situ hybridization for Sproutyl on isolated kidney tissues from E11.5 control $(n=17)$ and Fgfr $2^{\text {Mes-I- }}(n=10)$ embryos. In both controls and mutants, Sproutyl signal seems to be present in the stromal cells surrounding the nephric duct and main ureteric bud trunk (Fig. $9 a$ and $b$ ). To determine whether there was differential expression in the kidney itself, we sectioned and examined the stained tissues. In both control and Fgfr $2^{\mathrm{Mes-l-}}$ kidneys, we observed intense Sproutyl signal in the ureteric bud tips, and weaker signal in the surrounding metanephric mesenchyme (Fig. $9 c$ and $d$ ). We detected no signal with sense probe (data not shown). Thus, Sprouty1 expression seems to be unaltered in $\mathrm{Fgfr}^{\mathrm{Mes}-1-}$ mice.

Fgfr $^{\text {Mes-l- }}$ cultured nephric ducts are not more sensitive to exogenous GDNF. Because others have reported mutant mouse lines with increased sensitivity of cultured nephric ducts to exogenous GDNF (17), we examined effects of GDNF on E10.5 kidney primordia of control and Fgfr $2^{\text {Mes-l- }}$ mice. Both control and mutant nephric ducts had similar dose-dependent responses to GDNF. At $25 \mathrm{ng} / \mathrm{mL}$, controls had means of 2.73 ureteric buds $/ \mathrm{mm} \pm 1.12$ buds $/ \mathrm{mm}$ versus mutants with $2.29 \pm 1.31 \mathrm{buds} / \mathrm{mm}(p=0.41)$ (data not shown) and at $50 \mathrm{ng} / \mathrm{mL}$, controls averaged $3.97 \pm 1.83$ buds $/ \mathrm{mm}$ versus mutants with $3.83 \pm 1.03$ buds $/ \mathrm{mm}(p=$ 0.91) (Fig. 10). Thus, Fgfr2 $2^{\text {Mes-1- }}$ nephric ducts do not seem to be more sensitive to GDNF than controls.

\section{DISCUSSION}

Previous reports show that the $F g f r$ family functions in different stages and lineages of renal development (3-10). Among the $F g f$ receptors, $F g f r 2$ regulates ureteric bud and renal stromal patterning (from its expression in the ureteric bud) and in early metanephric mesenchymal development (secondary to its actions with Fgfrl in the renal mesenchyme) $(15,16)$. This report documents another role for Fgfr2 in the metanephric mesenchyme (i.e. ensuring that there is a single, properly positioned ureteric bud from the nephric duct). Moreover, $\mathrm{Fg} f \mathrm{r}^{\mathrm{Mes-1-}}$ mice frequently develop multiple ureteric bud induction sites resulting in urinary tract anomalies including renal aplasia, mis-shaped kidneys, partially duplicated kidneys, duplicated ureters, and hydroureter with obstructed insertion into the ductus deferens or paramesonephros.

Fgfr $2^{\text {Mes-l- }}$ mice are different from many other models with multiple ureteric buds in which there is such a wide spectrum of later urinary tract abnormalities and that the incidence of multiple ureteric buds $(67 \%)$ seems to be greater than the later renal anomalies (37\%). Regarding the latter point, it may be that with higher numbers of $\mathrm{Fgfr}^{\mathrm{Mes}-1-}$ 

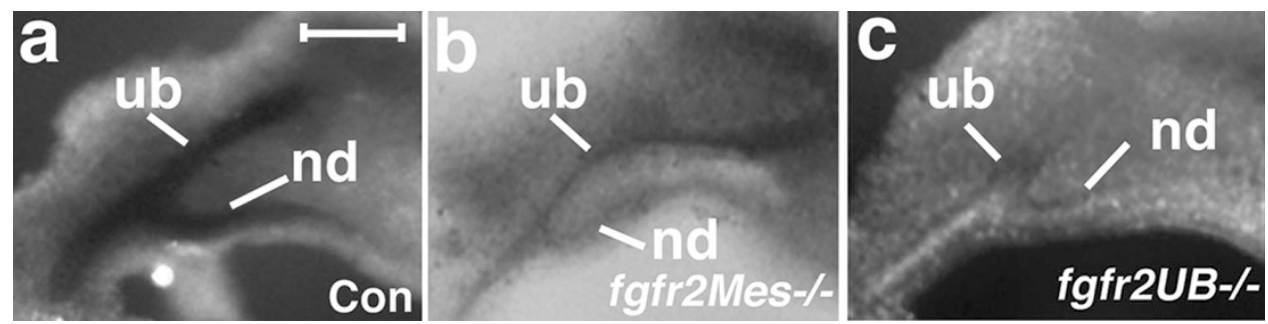

Figure 6. Whole mount in situ hybridization for Fgfr2 in E11.5 control, Fgfr $2^{M e s-/-}$, and Fgfr $2^{U B-/-}$ isolated kidneys. $a$, Control with a broad band of Fgfr2 expression that seems to be within the epithelium, in the adjacent stromal cells near the nephric duct (nd) and the ureteric bud (ub) at the induction site. $b$, $F g f r 2^{M e s-1-}$ kidney with a narrow band of $F g f r 2$ signal that appears confined to the epithelial cells of the tissues at the induction site. $c, F g f r 2^{U B-/-}$ kidney with linear Fgfr2 expression in stromal cells on either side of the nephric duct and ureteric bud near the induction site. Scale bar $=100 \mu \mathrm{m}$.
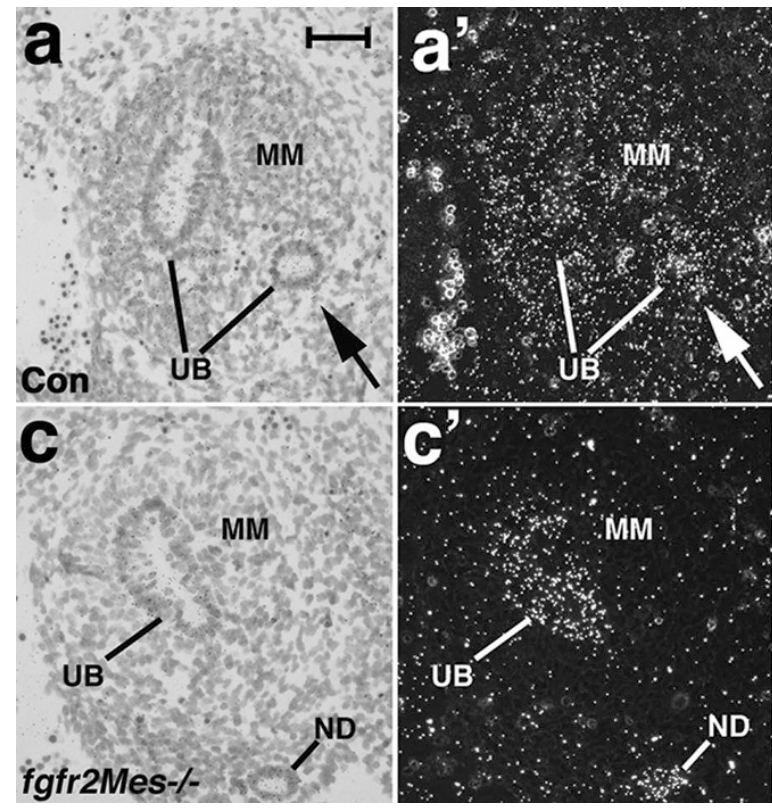

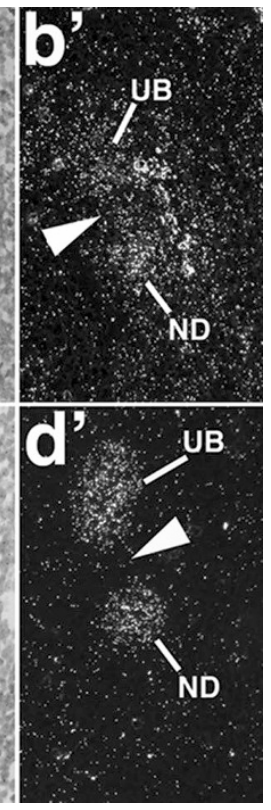

Figure 7. In situ hybridization for Fgfr2 in E11.5 control and Fgfr2 ${ }^{\text {Mes- }--}$ tissue sections. $a$ and $a$, Brightfield ( $a$ ) and darkfield $\left(a^{\prime}\right)$ images of controls with Fgfr2 expression in metanephric mesenchyme (MM), ureteric bud (UB) ampulla and trunk and in stromal cells adjacent to the trunk (arrow). $b$ and $b$ ', Control near junction of ureteric bud trunk and nephric duct (ND) showing Fgfr2 signal in both epithelium and stromal tissue between epithelia (arrowhead). c and c', Fgfr2 $2^{\text {Mes-1- }}$ revealing Fgfr2 is expressed in the ureteric bud within metanephric mesenchyme and early trunk leaving the kidney and in nephric duct but excluded from metanephric and stromal mesenchyme. $d$ and $d$, $\mathrm{Fgfr}^{\mathrm{Mes}-1-}$ embryo near junction of ureteric bud trunk and nephric duct shows Fgfr2 signal is present in the epithelium but excluded from the stromal cells in between. Scale bar $=25 \mu \mathrm{m}$. embryos analyzed, the incidence of early and later phenotypes would be the similar. Another plausible explanation for both findings, however, is that the two ureteric buds "compete" for contact with the metanephric mesenchyme. If the "normally positioned" ureteric bud made contact and the anterior bud regressed, there may be no apparent phenotype at later stages of renal development. Conversely, if the anterior ureteric bud alone made contact with the metanephric mesenchyme, chances are high that the resulting ureter would insert blindly into the ductus deferens or paramesonephros causing obstruction and hydroureter. Such phenotypes have been described in other mutants with ureteric buds that originate too anterior off the nephric duct (23). The renal agenesis seen in Fgfr $2^{\text {Mes-l- }}$ mice likely resulted from neither ureteric bud contacting the mesenchyme. When both ureteric buds do make contact, only one seems to induce a normal kidney, whereas the other is attached to a smaller misshaped kidney. Thus, it seems that only one of the two ureteric buds makes good or any contact with the metanephric mesenchyme in affected Fofr $2^{\text {Mes-l- }}$ mice, which could explain the incidence and variety of later stage renal defects.

The reason for multiple ureteric bud induction sites is not clear. As shown, GDNF and Robo2, two key molecules expressed in metanephric mesenchyme that control ureteric bud induction sites, were not altered in $\mathrm{Fgfr}^{\mathrm{Mes-1-}}$ mutants.
Thus, another potential explanation for the ureteric bud induction abnormalities would be perturbations in stromal mesenchymal cells surrounding the nephric duct and the base of the ureteric bud. Moreover, molecule(s) expressed in these cells seem to inhibit the interaction between GDNF with its receptor Ret and, thus, restricting the nephric duct to one site for ureteric bud induction (22). We speculated that if $F g f r 2$ were expressed in this cell population, that the Pax3cre transgenic line (used to make the $\mathrm{Fgfr}^{\mathrm{Mes}-{ }^{-}}$- mice) should delete the gene, based on previous cre recombinase expression data (16). By comparing whole mount in situ hybridization in control, Pax3cre-driven, and Hoxb7cre-driven Fgfr2 conditional knockout embryonic kidneys, we showed that Fgfr2 is expressed in stromal cells around the nephric duct and ureteric bud near its induction site, and that it is deleted from these cells in $\mathrm{Fg} f \mathrm{r}^{\mathrm{Mes}-I-}$ mice. We confirmed these findings by examining Fgfr2 expression in $F g f r 2^{M e s-1-}$ and control embryonic tissue sections by radioactive in situ hybridization. Thus, the role of $F g f r 2$ in preventing ectopic ureteric bud formation is more likely secondary to its presence in the stromal cells adjacent to the nephric duct and ureteric bud base.

Despite the potential role of $F g f r 2$ in stromal cells, we saw no changes in Bmp4 or Sprouty1 (which is expressed in ureteric epithelium, metanephric mesenchyme, and stromal 


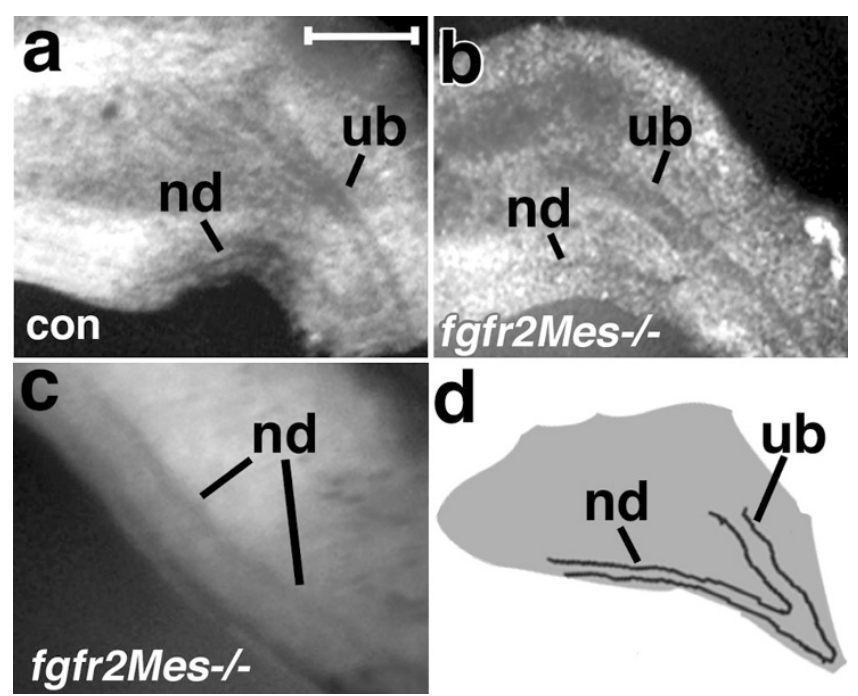

Figure 8. Whole mount in situ hybridization for Bmp4 in E11.5 control and F g fr2 ${ }^{\text {Mes-l- }}$ isolated kidneys. a, Control kidney with linear Bmp4 expression in stromal cells around the nephric duct (nd) and ureteric bud main trunk (ub). $b$ and $c$ : Lower magnification (b) and higher magnification (c) of $\mathrm{Fgfr}^{\mathrm{Mes}-1-}$ kidneys with similar linear Bmp4 signal in stromal mesenchyme adjacent to the nephric duct and ureteric bud. $d$, Diagram of Bmp4 expression in kidneys. Scale bar $=100 \mu \mathrm{m}$.
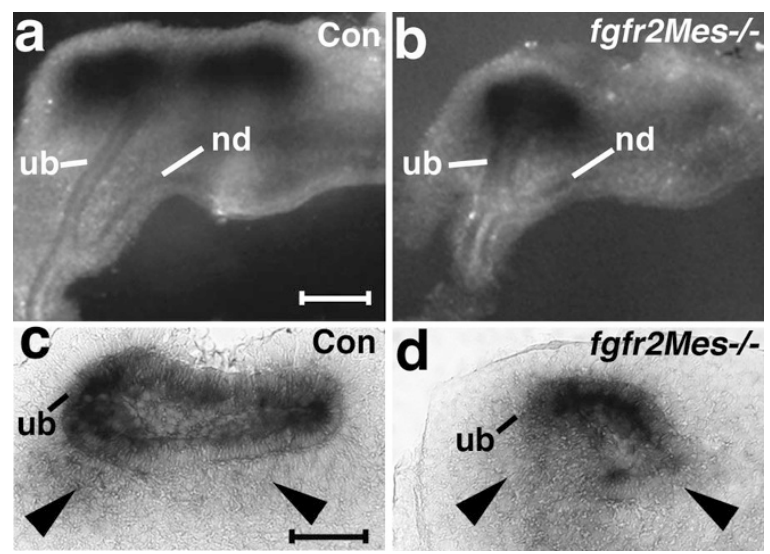

Figure 9. Whole mount in situ hybridization for Sprouty1 in E11.5 control and Fgfr $2^{\text {Mes-1- }}$ isolated kidneys. $a$ and $b$, Control $(a)$ and $F g f r 2^{\text {Mes-1- }}$ kidney $(b)$ both with linear Sproutyl expression in stromal cells around the nephric duct (nd) and ureteric bud main trunk (ub). $c$ and $d$, Sections through whole mount stained control (c) and Fgfr2 $2^{\text {Mes- }--}$ kidneys (d) both with strong Sproutyl expression in ureteric bud ampullae (ub) and weaker expression in surrounding metanephric mesenchyme (arrowheads). Scale bars $=100 \mu \mathrm{m}$.

mesenchyme). Furthermore, we saw no differences in the sensitivity of cultured Fgfr $2^{\text {Mes-I- }}$ nephric ducts versus controls to exogenous GDNF (although the in vitro culture system may not be sensitive enough to detect subtle differences). Novel downstream targets of $F g f r 2$ activity in the metanephric and/or stromal mesenchyme responsible for control of ureteric bud induction sites will be explored in the future.

Finally, the urinary tract anomalies in the Fgfr $2^{\text {Mes-l- }}$ mice may have clinical relevance. Activating mutations of Fgfr2 can cause urogenital abnormalities in humans including hydroureter and solitary kidney $(24,25)$. Human studies have also shown that specific structural renal anomalies seen in Fgfr2 ${ }^{\text {Mes-I- }}$ mice, such as renal agenesis, often occur in
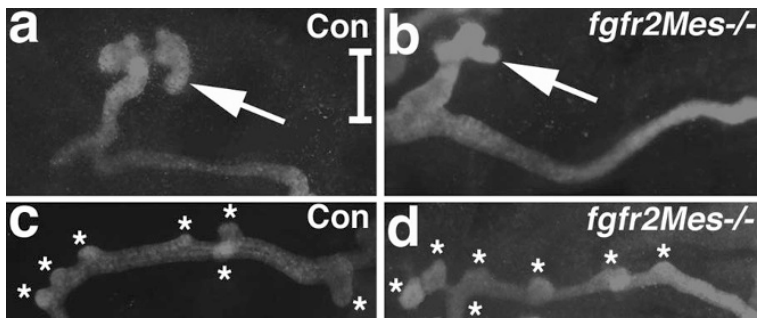

Figure 10. Response of control and $\mathrm{Fg} f \mathrm{r} \mathrm{2}^{\mathrm{Mes}-/-}$ E10.5 cultured nephric ducts to exogenous GDNF for 3 d. Both control (a) and Fgfr2 $2^{\text {Mes-l- }}$ (b) nephric ducts show single branched ureteric buds from nephric ducts with serum only. Control (c) and $\mathrm{Fgfr}^{\mathrm{Mes}-1-}($ d) nephric ducts develop similar numbers of ectopic ureteric buds in response to $50 \mathrm{ng} / \mathrm{mL}$ of exogenous GDNF. Scale bar $=25 \mu \mathrm{m}$.

familial clusters $(26,27)$. Other studies have shown that patients with renal agenesis/dysgenesis have relatives with a much higher rate of urinary tract anomalies than the general population, with phenotypes including duplicated ureters and unilateral renal agenesis, much as the $\mathrm{Fgfr}^{\mathrm{Mes}-1-}$ mice $(28,29)$. Finally, there have been a few reports showing how a known single genetic defect in humans may result in many renal malformations, often within the same family $(30,31)$. Thus, Fgfr2 or its ligands may be good candidate genes to screen for mutations in families that have a wide spectrum of renal anomalies.

Acknowledgments. We thank Dr. Jon Epstein for the Pax3cre mice, Dr. Janet Rossant for the floxed Fgfrl mice, and Dr. David Ornitz for the floxed $F g f r 2$ mice.

\section{REFERENCES}

1. Powers CJ, McLeskey SW, Wellstein A 2000 Fibroblast growth factors, their receptors and signaling. Endocr Relat Cancer 7:165-197

2. Dressler GR 2006 The cellular basis of kidney development. Annu Rev Cell Dev Biol 22:509-529

3. Barasch J, Qiao J, McWilliams G, Chen D, Oliver JA, Herzlinger D 1997 Ureteric bud cells secrete multiple factors, including bFGF, which rescue renal progenitors from apoptosis. Am J Physiol 273:F757-F767

4. Perantoni AO, Dove LF, Karavanova I 1995 Basic fibroblast growth factor can mediate the early inductive events in renal development. Proc Natl Acad Sci USA 92:4696-4700

5. Celli G, LaRochelle WJ, Mackem S, Sharp R, Merlino G 1998 Soluble dominantnegative receptor uncovers essential roles for fibroblast growth factors in multiorgan induction and patterning. EMBO J 17:1642-1655

6. Ohuchi H, Hori Y, Yamasaki M, Harada H, Sekine K, Kato S, Itoh N 2000 FGF10 acts as a major ligand for FGF receptor 2 IIIb in mouse multi-organ development. Biochem Biophys Res Commun 277:643-649

7. Qiao J, Uzzo R, Obara-Ishihara T, Degenstein L, Fuchs E, Herzlinger D 1999 FGF-7 modulates ureteric bud growth and nephron number in the developing kidney. Development 126:547-554

8. Revest JM, Spencer-Dene B, Kerr K, De Moerlooze L, Rosewell I, Dickson C 2001 Fibroblast growth factor receptor 2-IIIb acts upstream of Shh and Fgf4 and is required for limb bud maintenance but not for the induction of Fgf8, Fgf10, Msx1, or Bmp4. Dev Biol 231:47-62

9. Grieshammer U, Cebrian C, Ilagan R, Meyers E, Herzlinger D, Martin GR 2005 FGF8 is required for cell survival at distinct stages of nephrogenesis and for regulation of gene expression in nascent nephrons. Development 132:3847-3857

10. Perantoni AO, Timofeeva O, Naillat F, Richman C, Pajni-Underwood S, Wilson C, Vainio S, Dove LF, Lewandoski M 2005 Inactivation of FGF8 in early mesoderm reveals an essential role in kidney development. Development 132:3859-3871

11. Arman E, Haffner-Krausz R, Chen Y, Heath JK, Lonai P 1998 Targeted disruption of fibroblast growth factor (FGF) receptor 2 suggests a role for FGF signaling in pregastrulation mammalian development. Proc Natl Acad Sci USA 95:5082-5087

12. Deng CX, Wynshaw-Boris A, Shen MM, Daugherty C, Ornitz DM, Leder P 1994 Murine FGFR-1 is required for early postimplantation growth and axial organization. Genes Dev 8:3045-3057

13. Xu X, Weinstein M, Li C, Naski M, Cohen RI, Ornitz DM, Leder P, Deng C 1998 Fibroblast growth factor receptor 2 (FGFR2)-mediated reciprocal regulation loop between FGF8 and FGF10 is essential for limb induction. Development 125:753765 
14. Yamaguchi TP, Harpal K, Henkemeyer M, Rossant J 1994 fgfr-1 is required for embryonic growth and mesodermal patterning during mouse gastrulation. Genes Dev 8:3032-3044

15. Zhao H, Kegg H, Grady S, Truong HT, Robinson ML, Baum M, Bates CM 2004 Role of fibroblast growth factor receptors 1 and 2 in the ureteric bud. Dev Biol 276:403-415

16. Poladia DP, Kish K, Kutay B, Hains D, Kegg H, Zhao H, Bates CM 2006 Role of fibroblast growth factor receptors 1 and 2 in the metanephric mesenchyme. Dev Biol 291:325-339

17. Basson MA, Akbulut S, Watson-Johnson J, Simon R, Carroll TJ, Shakya R, Gross I, Martin GR, Lufkin T, McMahon AP, Wilson PD, Costantini FD, Mason IJ, Licht JD 2005 Sprouty1 is a critical regulator of GDNF/RET-mediated kidney induction. Dev Cell 8:229-239

18. Michos O, Goncalves A, Lopez-Rios J, Tiecke E, Naillat F, Beier K, Galli A, Vainio S, Zeller R 2007 Reduction of BMP4 activity by gremlin 1 enables ureteric bud outgrowth and GDNF/WNT11 feedback signaling during kidney branching morphogenesis. Development 134:2397-2405

19. Sims-Lucas S, Caruana G, Dowling J, Kett MM, Bertram JF 2008 Augmented and accelerated nephrogenesis in TGF-beta2 heterozygous mutant mice. Pediatr Res 63:607-612

20. Grieshammer U, Le M, Plump AS, Wang F, Tessier-Lavigne M, Martin GR 2004 SLIT2-mediated ROBO2 signaling restricts kidney induction to a single site. Dev Cell 6:709-717

21. Kume T, Deng K, Hogan BL 2000 Murine forkhead/winged helix genes Foxc1 (Mf1) and Foxc2 (Mfh1) are required for the early organogenesis of the kidney and urinary tract. Development 127:1387-1395
22. Miyazaki Y, Oshima K, Fogo A, Hogan BL, Ichikawa I 2000 Bone morphogenetic protein 4 regulates the budding site and elongation of the mouse ureter. J Clin Invest 105:863-873

23. Batourina E, Tsai S, Lambert S, Sprenkle P, Viana R, Dutta S, Hensle T, Wang F, Niederreither K, McMahon AP, Carroll TJ, Mendelsohn CL 2005 Apoptosis induced by vitamin A signaling is crucial for connecting the ureters to the bladder. Nat Genet 37:1082-1089

24. Cohen MM Jr, Kreiborg S 1993 Visceral anomalies in the Apert syndrome. Am J Med Genet 45:758-760

25. Passos-Bueno MR, Wilcox WR, Jabs EW, Sertie AL, Alonso LG, Kitoh H 1999 Clinical spectrum of fibroblast growth factor receptor mutations. Hum Mutat $14: 115-125$

26. Arfeen S, Rosborough D, Luger AM, Nolph KD 1993 Familial unilateral renal agenesis and focal and segmental glomerulosclerosis. Am J Kidney Dis 21:663-668

27. Murugasu B, Cole BR, Hawkins EP, Blanton SH, Conley SB, Portman RJ 1991 Familial renal adysplasia. Am J Kidney Dis 18:490-494

28. Schwaderer AL, Bates CM, McHugh KM, McBride KL 2007 Renal anomalies in family members of infants with bilateral renal agenesis/adysplasia. Pediatr Nephrol 22:52-56

29. Roodhooft AM, Birnholz JC, Holmes LB 1984 Familial nature of congenital absence and severe dysgenesis of both kidneys. N Engl J Med 310:1341-1345

30. Sanyanusin P, Schimmenti LA, McNoe LA, Ward TA, Pierpont ME, Sullivan MJ, Dobyns WB, Eccles MR 1995 Mutation of the PAX2 gene in a family with optic nerve colobomas, renal anomalies and vesicoureteral reflux. Nat Genet 9:358-364

31. Carmi R, Binshtock M, Abeliovich D, Bar-Ziv J 1983 The branchio-oto-renal (BOR) syndrome: report of bilateral renal agenesis in three sibs. Am J Med Genet $14: 625-627$ 